\title{
COLUBER NAJA.
}

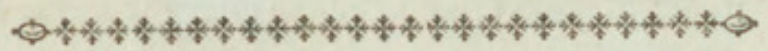

Colubrum Najam, collo paulatim tumefcente et expanfo, molliter tantum irafcentem in hoc opere antea depinximus. Cum vero veram et archetypam figuram, quam de ipfo vivo ferpente delineavit in India pictor, quæque illum furibundum et jam jam morfurum oftendit, amicifime communicavit Dominus Ruffel, eam nunc lubentiffime protulimus, ut clarius et melius innotefcat quicquid ad formidandi hujus animalis hiftoriam aliquo modo fpectare poffit. 


\section{'T HE \\ SPECTACLE SNAKE.}

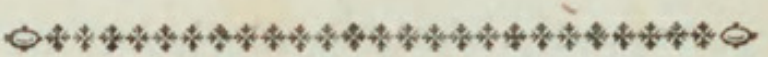

The figure of Coluber Naja in a preceding number of this work reprefenting the fnake merely in an approach towards that expanded ftate which the neck affumes when the animal is preparing to bite, and having been fince favoured by Dr. Ruflel with an original drawing executed in India and accurately reprefenting the creature in its ftate of irritation, I therefore embrace fo favourable an opportunity of giving an additional figure, as a farther and clearer elucidation of the hiftory of this dangerous reptile. 


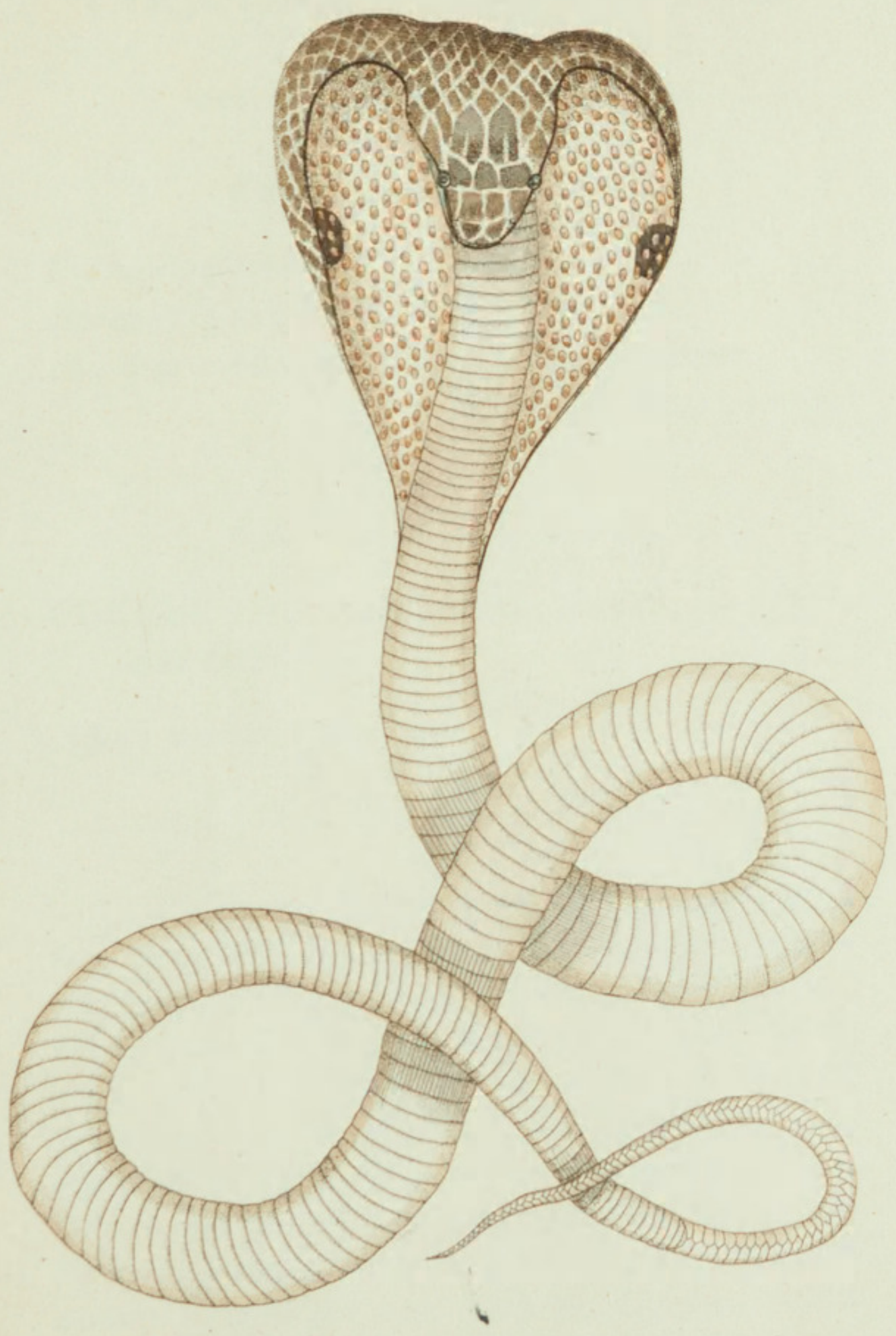




\section{$2 \mathrm{BHL}$ Biodiversity Heritage Library}

Shaw, George. 1794. "The Spectacle Snake, Coluber naja [PI. 181]." The Naturalist's Miscellany 5(LIX), https://doi.org/10.5962/p.310760.

View This Item Online: https://www.biodiversitylibrary.org/item/276340

DOI: https://doi.org/10.5962/p.310760

Permalink: https://www.biodiversitylibrary.org/partpdf/310760

\section{Holding Institution}

Museums Victoria

\section{Sponsored by}

Atlas of Living Australia

\section{Copyright \& Reuse}

Copyright Status: Public domain. The BHL considers that this work is no longer under copyright protection.

This document was created from content at the Biodiversity Heritage Library, the world's largest open access digital library for biodiversity literature and archives. Visit BHL at https://www.biodiversitylibrary.org. 